\title{
In Search for Holistic ICT4D Research: A Systematic Literature Review
}

\author{
Luthfi Ramadani \\ The University of Melbourne \\ 1ramadani@student.unimelb.edu.au
}

\author{
Sherah Kurnia \\ The University of Melbourne \\ sherahk@unimelb.edu.au
}

\author{
Christoph F. Breidbach \\ The University of Melbourne \\ christoph.breidbach@unimelb.edu.au
}

\begin{abstract}
The technologist vs. contextualist debate has divided Information and Communications Technology for Development (ICT4D) research. Today, the field is disconnected across three distinct research streams, which should be consolidated into a more holistic discourse. However, this endeavor remained unfeasible to date, because the similarities and differences of these ICT4D streams had not been clearly conceptualized. Our present work addresses this gap in knowledge through a systematic review of extant ICT4D research from 2007-2016. We provide an indepth analysis of 48 articles, identify and discuss the characteristics of each research stream, and offer new insights on how knowledge in the field might be consolidated into a more holistic fashion.
\end{abstract}

\section{Introduction}

Information and Communications Technology for Development (ICT4D) research is a field that seeks to diminish the digital divide by exploring how information systems and technology can be applied to developing countries [1]. However, despite being a relatively mature field, ICT4D research repeatedly witnessed the failure of ICT projects, ranging from telephone and satellite communication in Africa as early as the 1960s [2], to computer system implementations in India and Latin America in 1990s [3], to diverse e-government projects in Southeast Asia in the 2000s [4]. Consequently, much debate arose as to why ICT4D project fail fully or partially [5]. Eventually, the focus on ICTs in much ICT4D research, which considers the impact of ICTs on developing countries as linear and deterministic $[6,7]$, was seen as a potential culprit because it fails to acknowledge social structures in developing countries [8], as well as unique cultures, political motives, or institutional rules [9]. To date, ICT4D research is divided into two general schools of thought; contextualism, which is concerned with how to explore the social context $[10,11,12]$, and technology-transfer that concerns how to catch up with the rapid technological development from developed countries $[13,14]$. Though most studies in each stream discuss both ICTs and the development, the focus and approach are significantly different, for example due to varying theoretical lenses, research method, or unit of analysis $[15,16]$.

Here, we argue that both research trajectories should not be perceived as mutually exclusive, but be integrated into a holistic approach. There are countless examples stemming from research taking an isolated perspective on technology and context. For example, Gera et al. [17] and Sahay [18] reported the nationwide 'Mother and Child Tracking System' (MCTS) in India was solely motivated by technical capabilities, yet without acknowledging the complexity of the context, resulted in systemic failures. On the other hand, purely contextual ICT4D research obscures the interests in the macro-level context, generates too specific solutions, and are unsustainable [8, 19].

Calls for broader ICT4D research that combine the characteristics of both streams repeatedly emerged [16, 20, 21, 22]. Such broader ICT4D research could offer meaningful outcomes at a micro-level, as well as a conclusive and convincing macro-lens for policy makers or technology-vendors [19, 23]. This quest, however, is considered challenging, since "research that spans micro-macro analytical domains in the social sciences is notoriously difficult" [16, p. 12]. Thus, we argue that it is initially necessary to understand the characteristics of each stream before striving for further integration. However, such knowledge is not available to date. Therefore, our work aims to take a fundamental step toward a broader and more holistic view of ICT4D research, by reviewing extant research trajectories, and by proposing clear avenues for consolidation through a systematic literature review. We recall and reconceptualize the ICT4D discourses by Avgerou [15] and identify the trend and use of each stream in the last ten years in the IS literature. We identify the theoretical lens, research approach, and means of development, and then discuss the prospect on consolidating them into a broader perspective of ICT4D research as future research trajectory. As such, this systematic literature review will provide valuable 
insights for those who seek a holistic approach to ICT4D research.

This paper is structured as follows: We initially discuss currently known streams of ICT4D research, before presenting our research method. The manuscript then presents the results and concludes with an indepth discussion and future research opportunities.

\section{Streams of ICT4D Research}

In the early years, ICT4D research was largely influenced by Rogers' [24] Diffusion of Innovation (DOI) theory. Within the mainstream IS research, the concepts of DOI have been applied in Davis's [13] Technology Acceptance Model (TAM) and later extended to Unified Theory of Acceptance and Use of Technology (UTAUT) [14]. Though these theories are widely applied in ICT4D studies, the nature of the concepts are subject to criticism $[6,25]$. The central paradigm of the DOI theory related to the way technology innovation is spreading within the society indicates the deterministic nature of innovation during the diffusion process. The main objective of studies employing DOI or other related theories is typically to measure members' response (e.g. acceptance, perception, or use). Therefore, the role of the society is usually not considered. Further, such studies do not generally provide a rich understanding of technological innovation acceptance and diffusion process within the society because of the narrow focus and lack of depth in exploring the social context.

Many scholars have highlighted the shortcomings of studies with a technology deterministic viewpoint by demonstrating bidirectional interactions between technology and the adopters $[6,8,25,26]$. This stance attempts to leverage the importance of understanding the social context in ICT4D research and to observe its interactions with the technology. Further, in some cases, the social context could determine the shape of appropriate technological innovations particularly for vulnerable groups. The significance of social context later invited a new wave of ICT4D research.

Table 1. ICT4D Streams (based on Avgerou [15])

\begin{tabular}{|c|c|c|}
\hline Streams & Description & Properties \\
\hline $\begin{array}{l}\text { Technology- } \\
\text { transfer }\end{array}$ & $\begin{array}{l}\text { Catching up with technological } \\
\text { advancement of developed } \\
\text { countries through transfer and } \\
\text { adoption. }\end{array}$ & $\begin{array}{l}\text { - Seeks to find the relevance of established IS research knowledge } \\
\text { and good practice models (e.g. methods, analytical approaches, or } \\
\text { theories) and adaptation in developing countries context. } \\
\text { - Related theories: DOI, TAM, UTAUT, established IS concepts or } \\
\text { best practices such as organizational change and IS management. }\end{array}$ \\
\hline $\begin{array}{l}\text { Social- } \\
\text { embeddedness }\end{array}$ & $\begin{array}{l}\text { Constructing new socio- } \\
\text { technical structures according to } \\
\text { the given local social context } \\
\text { and the constellation of actors. }\end{array}$ & $\begin{array}{l}\text { - Seeks to adequately comprehend the social situation where the } \\
\text { technology takes place. } \\
\text { - Frequently use social science rooted theories: Actor-Network } \\
\text { Theory (ANT), institutional theory, complexity, social network. }\end{array}$ \\
\hline $\begin{array}{l}\text { Transformative } \\
\text { ICT4D }\end{array}$ & $\begin{array}{l}\text { Creating possibilities for the } \\
\text { improvement of life conditions } \\
\text { with a deep and significant } \\
\text { socio-economic change through } \\
\text { ICT interventions. }\end{array}$ & $\begin{array}{l}\text { - Might use the same theoretical lenses with social-embedded } \\
\text { stream. } \\
\text { - Focuses on the mechanism of resolving the development struggle } \\
\text { of the social context through ICT-enabled transformation either by } \\
\text { solving the vulnerabilities or by improving capabilities. }\end{array}$ \\
\hline
\end{tabular}

Table 1 presents the three streams of ICT4D research identified by Avgerou [15]: 1) technology transfer 2) social-embeddedness, and 3) transformative ICT4D. Technology transfer stream focuses on how developing countries can catch up with technological advancement in developed countries, including the related knowledge and best practices. These technologies and practices, however, need to be appropriated to suit the local contexts. Socialembeddedness stream deals with exploring and investigating the interplay between technology and society that may lead to establishment of new sociotechnical structures. It focuses on the way how local actors interpret, institutionalize, and accommodate the technology into their lives. Transformative ICT4D stream, though also heavily engages with social context, is different from social-embedded stream in two ways: 1) it focuses on specific "development struggle" $[15$, p. 136] in a "particular locality amidst the global socio-economic order" [15, p. 135], and 2) it uncovers the process by which the ICT leverages and improve people lives [15, see p. 142-143]. This stream explicitly deals with the vulnerabilities of the social context and is concerned with how ICT can transform the target community to improve the standard of living and the quality of life in general. The descriptions and properties of each stream are summarized in Table 1.

\section{Research Method}

The primary literature sources used in this study include all eight IS senior scholar basket of journals (European Journal of Information Systems, Information Systems Journal, Information Systems 
Research, Journal of AIS, Journal of Information Technology, Journal of Management Information Systems, Journal of Strategic Information Systems, MIS Quarterly) and other notable IS outlets; Decision Support Systems, Information and Management, Information and Organization, and International Journal of Medical Informatics. To expand the source selection, other Q2-ranked IS journals based on SCImago journal indicator that publish ICT4D research were selected: Information Technology and People, Information Systems Frontiers, International Journal of Information Management, and The Information Society. In our review, we used top IS outlets to address the challenge faced by previous scholars that examined specialized ICT4D outlets. Those authors contend that such publications were dominated by best practices and field experiences so it was difficult to clarify the research elements such as the notions of development [27] or the means of theoretical contributions [28] which are important for future development of the field.

A series the search was undertaken using Scopus citation database by several combinations of keywords: 'information technology', 'information systems', 'information and communication technologies', ICT, 'developing countries', and 'least developed countries'. In addition, similar terms with ICT4D were used in searching process, including ITID - Information Technologies and International Development [29], ISDC - Information Systems in Developing Countries [15], ICTD - Information and Communication Technologies for Development [16, 27], and LSD Least Developed Countries [30]. The combination of these keywords helped us cover all publications related to ICT 'in developing countries' and ICT 'for development' [31]. Table 2 shows the keyword combination used in screening the articles. To have a manageable scope, we focused only on the articles published from 2007-2016.

Table 2. Keyword Combinations

\begin{tabular}{|c|c|c|c|c|}
\hline \multicolumn{3}{|c|}{ ICT 'in Developing Countries' } & \multicolumn{2}{|c|}{$\begin{array}{c}\text { ICT 'For } \\
\text { Development' }\end{array}$} \\
\hline \multicolumn{5}{|c|}{ Title-Abstract-Keywords } \\
\hline $\begin{array}{l}\text { "information } \\
\text { system*", } \\
\text { "information } \\
\text { technolog*", } \\
\text { "information and } \\
\text { communication } \\
\text { technolog*" }\end{array}$ & AND & $\begin{array}{l}\text { "developing } \\
\text { countr*", } \\
\text { "least } \\
\text { developed } \\
\text { countr*" }\end{array}$ & OR & $\begin{array}{c}\text { ICT4D, } \\
\text { ICTD, } \\
\text { ISDC, } \\
\text { ITID }\end{array}$ \\
\hline
\end{tabular}

The initial search identified 131 articles, excluding editorial and review articles (based on Scopus system). Then, these results were verified by reading the title, abstract, and followed by full-text reading. The criteria of article exclusions were inductively established during the selection process. Those studies that do not contribute primarily to the knowledge related to ICT in the developing countries were removed. For example, articles focused on software-systems development, knowledge management, strategic IS, or other disciplines such as the economy, development studies, and sociology were excluded. Next, the articles that do not focus on bridging the ICT and development in the developing countries were also omitted. For examples, papers related to developing countries that do not contribute to the ICT4D field or general IS field were excluded. Many conceptual papers were omitted as they would not contribute to our analysis on ICT4D streams. The most difficult part was to justify the suitability and relevance of papers for each of the three streams in ICT4D research during our literature search and analysis. The final dataset (48 articles) was obtained after several rounds of reading and screening.

\section{Findings}

\subsection{Overview}

Table 3 presents the studies found in each of the three ICT4D streams. The results show that the technology transfer viewpoint is still dominant. This observation confirms previous studies published in specialized ICT4D outlets, suggesting that the topdown approach (externally-defined solutions to be locally implemented) dominates the literature three times as much as the bottom-up approach (where local stakeholders have a strong influence in problem definition and articulation of solutions) [27, p. 14].

Table 3. General Findings

\begin{tabular}{|c|c|c|}
\hline Streams & \#counts & Articles \\
\hline $\begin{array}{l}\text { Technology } \\
\text { transfer stream }\end{array}$ & 28 & $\begin{array}{l}{[4,32,33,34,35,36,37,} \\
38,39,40,41,42,43,44, \\
45,46,47,48,49,50,51, \\
52,53,54,55,56,57,58]\end{array}$ \\
\hline $\begin{array}{l}\text { Social } \\
\text { embeddedness } \\
\text { stream }\end{array}$ & 15 & $\begin{array}{l}{[6,8,11,12,19,21,22,} \\
25,26,59,60,61,62,63, \\
64]\end{array}$ \\
\hline $\begin{array}{l}\text { Transformative } \\
\text { ICT4D stream }\end{array}$ & 5 & {$[65,66,67,68,69]$} \\
\hline
\end{tabular}

\subsection{Technology-transfer}

Despite the criticism on this traditional stream, the technology-transfer viewpoint is still the most popular. In general, the majority of studies in this stream applied quantitative inquiry to investigate the phenomena of new ICT adoption in developing countries. Those studies typically conducted a survey 
involving users (citizen, consumer) [4, 38, 51, 54, 55] or company representatives (managerial or C-level) $[34,37,43,45,48,53]$ to get a broad understanding of user perception, technology use, and organizations' readiness for the new ICT systems. These studies aim to engage with introduction and penetration of new technology in developing countries such as Executive Information Systems [33], public ICT (libraries, telecentre, cybercafes) [46], internet banking [50], cloud computing [53, 57], e-government [4, 36, 37, 51, 54, 55], and e-commerce [34, 47, 56]. Another topic identified within this stream is related to investigation of the availability of supporting systems in countrylevel to provide platforms for new ICT systems, such as national infrastructure and ICT policies [42, 44, 45] and human resources [66]. Several econometric analyses linking IT investment and performances (e.g. productivity or economic outcomes) were also found in this stream [32, 48, 52].

The technology-transfer studies are considered useful and effective in presenting a conclusive report about ICT4D projects to non-IS entities in the macrolevel (e.g. vendors, NGOs, and government). The study's findings are primarily about the degree of users' acceptance and general impact of ICT investment. This sort of findings is, of course, more conclusive and definitive by the business, NGOs, or policy maker in macro-level rather than qualitative elaboration from bottom-level implementation. For example, a study with a conclusion that ICT investment directly improves productivity in developing countries might be more expected by nonIS entities [44, 48, 52]. Similarly, a study that hypothesizes the quality of web-design affects the consumer's intentions to use the e-banking [50] would be of importance to vendors or developers. Furthermore, from researchers' perspective, the theoretical lenses, such as Roger's (1962) Diffusion of Innovation (DOI), and the IS adoption theories such as Technology Acceptance Model (TAM) [13] and Unified Theory of Acceptance and Use of Technology (UTAUT) [14] were continuously becoming useful as they offer practical guidelines for scholars in conducting ICT4D research. As shown in Figure 1, these theories have been widely used in the literature in the last ten years.

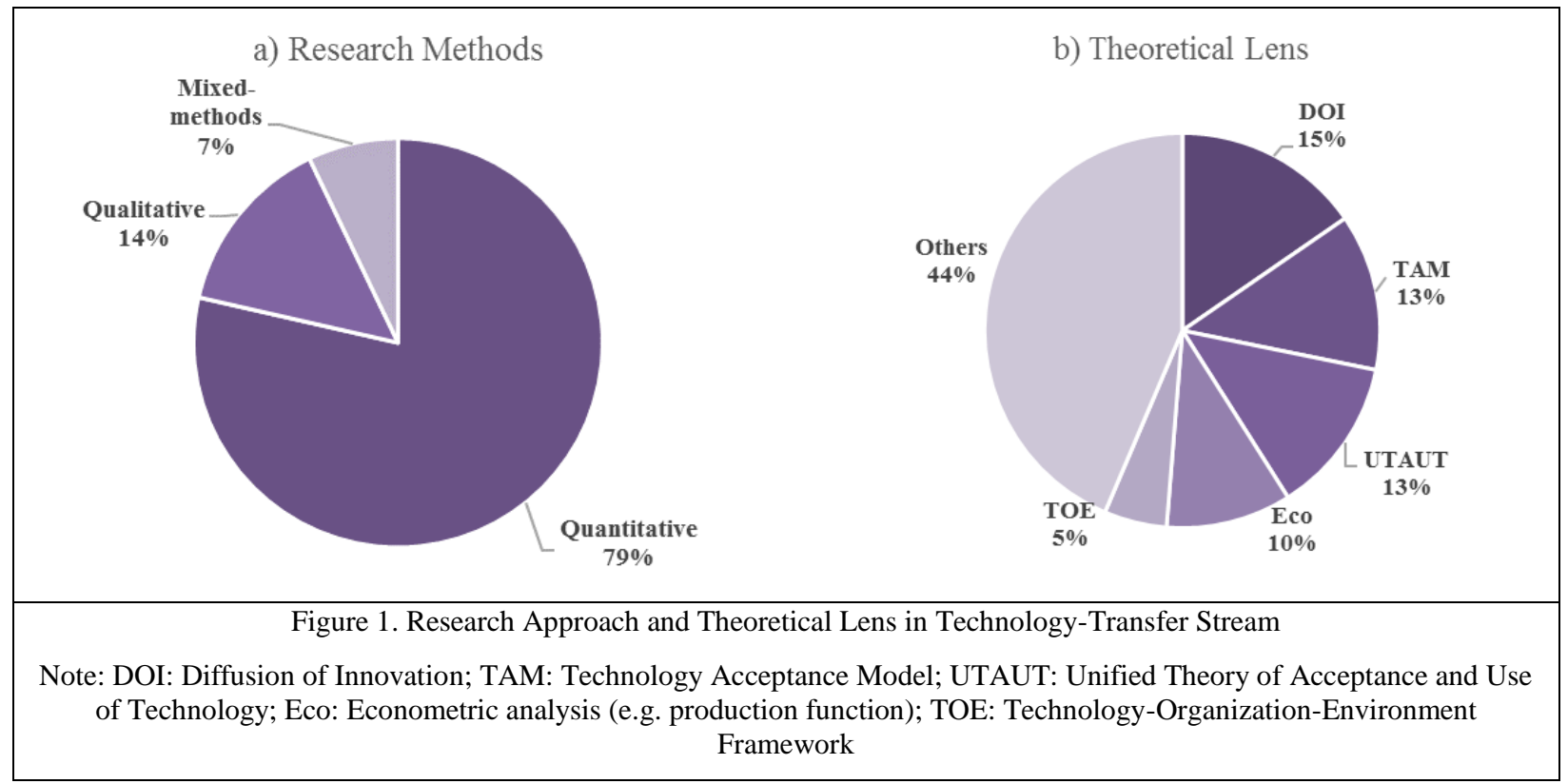

\subsection{Social-embeddedness}

In general, the social-embedded studies attempt to resolve the lack of in-depth explanation of the social context of ICT4D in technology-transfer stream. Some of the studies in this stream focus on exploring the micro-level characteristics such as infrastructure, level of literacy, or language barriers, and then propose a bottom-up solution of ICT [11, 12]. Other studies extend the bottom-up approach by exploring microlevel and macro-level characteristics simultaneously to explore the tangled relationship, hierarchical positions, interests, and concerns of all stakeholders [19, 26]. Consequently, these studies attempt to broaden the scope of analysis especially by linking the social context situation at micro-level with related actors' interests at macro-level by conducting multilevel unit of analysis. This approach is significant because it 
considers multi-actors concerns toward ICT adoption to reveal whether the project is fully supported in any possible ways (e.g. resources, regulation, political power).

Thereby, the social embedded studies which broaden the scope of analysis offer significant insights into multi-actors' concerns in regard of ICT. These studies are supported by a proper theoretical lens or analytical frameworks, ranging from complexity science [59], institutional theory [6, 64], ActorNetwork Theory (ANT) [60], or critical-realist research using morphogenetic analysis [21] and postcolonial theory [22]. The challenge remains on how a complex understanding of the context helps us broaden ICT4D research, especially in dealing with funding support, policy maker, or NGOs. Therefore, several studies have attempted to link the social context situation at micro-level with related actors' interests at macro-level by conducting multilevel unit of analysis. In this paper, we highlight this approach as a key characteristic of the social-embedded stream that distinct them with technology-transfer or transformative stream. Table 4 presents how this type of papers identifies the issues of complex social context emerged in the ICT4D project and how authors link the social levels.

It is interesting to note that from 11 articles that conducted a multilevel unit of analysis, seven of them are from the social-embedded stream. These studies investigate both macro-level policy and perception and micro-level implementation and what interplay occurs in such projects. The others concentrate on the context and then outline macro-level implications. As such, we argued that social-embedded research could effectively achieve broader and holistic ICT4D research by involving a multilevel unit of analysis in the study design.

Table 4. Social-Embedded with Multilevel Analysis

\begin{tabular}{|c|c|c|c|}
\hline Articles & Issues in ICT4D as a complex social event & Analytical lens & How did authors link the social levels? \\
\hline Gao [60] & $\begin{array}{l}\text { The conflict of interests among multiple } \\
\text { actors emerged in a nation ICT } \\
\text { infrastructure program }\end{array}$ & $\begin{array}{l}\text { Actor Network } \\
\text { Theory }\end{array}$ & $\begin{array}{l}\text { Depict and group the actors according to } \\
\text { their enrolment within the network and } \\
\text { examine the context affecting the ICT } \\
\text { implementation }\end{array}$ \\
\hline $\begin{array}{l}\text { Madon et } \\
\text { al. [19] }\end{array}$ & $\begin{array}{l}\text { The disjuncture between implementation } \\
\text { at micro-level and the policy at macro- } \\
\text { level of e-government project }\end{array}$ & $\begin{array}{l}\text { Social science's } \\
\text { evaluation approach }\end{array}$ & $\begin{array}{l}\text { Situation analysis on key-enablers in each } \\
\text { level and propose an integrated } \\
\text { implementation strategy }\end{array}$ \\
\hline $\begin{array}{l}\text { Puri et al. } \\
\text { [62] }\end{array}$ & $\begin{array}{l}\text { The complexity of Health Information } \\
\text { Systems (HIS) implementation in } \\
\text { developing context }\end{array}$ & $\begin{array}{l}\text { Participatory IS } \\
\text { design }\end{array}$ & $\begin{array}{l}\text { Using network-perspective, the authors } \\
\text { established the clear role and contribution of } \\
\text { all beneficiaries in all level }\end{array}$ \\
\hline $\begin{array}{c}\text { Brown } \\
\text { and } \\
\text { Thompson } \\
{[6]}\end{array}$ & $\begin{array}{l}\text { The needs to depict a complex setting of } \\
\text { actors, policies, and practices in ICT } \\
\text { implementation }\end{array}$ & Institutional theory & $\begin{array}{l}\text { Identify the policies (macro), practices } \\
\text { (micro), and actors (both) and explicate the } \\
\text { institutional logic subsequently }\end{array}$ \\
\hline $\begin{array}{l}\text { Hayes and } \\
\text { Westrup } \\
{[8]}\end{array}$ & $\begin{array}{l}\text { The needs to articulate the holistic } \\
\text { outcomes of ICT4D in a broader context }\end{array}$ & Social context & $\begin{array}{l}\text { Explore the processes in both macro-level } \\
\text { and micro-level actors as an integrated } \\
\text { context }\end{array}$ \\
\hline $\begin{array}{l}\text { Njihia and } \\
\text { Merali } \\
{[21]}\end{array}$ & $\begin{array}{l}\text { The needs to decompose the complexity of } \\
\text { nation-wide ICT4D project }\end{array}$ & $\begin{array}{l}\text { Morphogenetic } \\
\text { analysis }\end{array}$ & $\begin{array}{l}\text { Structural and cultural analysis according to } \\
\text { social theory's morphogenetic approach }\end{array}$ \\
\hline $\begin{array}{l}\text { Lin et al. } \\
\text { [22] }\end{array}$ & $\begin{array}{l}\text { The disjuncture between implementation } \\
\text { at micro-level and the perception at macro- } \\
\text { level }\end{array}$ & Postcolonial theory & $\begin{array}{l}\text { Evaluate the reality in the micro-level and } \\
\text { compare with the overall report provided by } \\
\text { macro-level actors }\end{array}$ \\
\hline
\end{tabular}

\subsection{Transformative ICT}

The papers in this stream especially dealt with the transformative power of ICT in social, economic, and political change in developing countries. Unlike the social-embedded studies which at certain degree "tend to take social, economic, and political conditions as given" [15, p. 136], transformative studies explicitly engage with the role and processual mechanism of ICT-enabled transformation such as poverty reduction, rural development, and political stabilization. In most cases, the role of researchers was not to discuss the socially-constructed structure (as in social-embedded). Rather, the researchers should go through an in-depth investigation into how ICTs entangle particular vulnerabilities and leverage capabilities in developing countries. This premise is fundamental to justify whether a paper is classified as transformative or social-embedded research stream. For example, when we were trying to classify a paper by Miscione [64], though the context is an isolated group in a remote location in Amazon, the focus of the research is the preference of social actors in the design of telemedicine system (which is the core characteristic of 
social-embedded stream), rather than how telemedicine transforms or improves local health.

In brief, most of these studies used qualitative and inductive inquiries for their approach [66, 67, 68], or illustrative case studies to promote their framework [65], focusing on community-level as a unit of analysis. The study by Venkatesh et al. [69], on the other hand, employ mixed methods involving both quantitative approach using longitudinal data and qualitative exploration for a deeper understanding of how internet kiosk intervenes the legacy custom and myth on mother and infant health. Table 5 presents the summary of the selected articles within this stream.

Table 5. Transformative ICT Stream

\begin{tabular}{|c|l|l|l|l|}
\hline Article & \multicolumn{1}{|c|}{$\begin{array}{c}\text { Development } \\
\text { Struggle }\end{array}$} & $\begin{array}{c}\text { Theoretical } \\
\text { Lens }\end{array}$ & \multicolumn{1}{|c|}{ Mechanism of the Transformation } & \multicolumn{1}{c|}{ Role of ICT } \\
\hline $\begin{array}{c}\text { Urquhart } \\
\text { et al. [65] }\end{array}$ & Poverty reduction & $\begin{array}{l}\text { Coleman's } \\
\text { social capital }\end{array}$ & $\begin{array}{l}\text { Enable three core dimensions of social } \\
\text { capital; (cap)ability, opportunity, and } \\
\text { motivation (based on illustrative case } \\
\text { studies) }\end{array}$ & $\begin{array}{l}\text { Increase access to education, } \\
\text { health, and financial services }\end{array}$ \\
\hline $\begin{array}{c}\text { Adam and } \\
\text { Urquhart } \\
\text { [66] }\end{array}$ & $\begin{array}{l}\text { Capacity building } \\
\text { in isolated area }\end{array}$ & Social capital & $\begin{array}{l}\text { Create an opportunity for broader } \\
\text { collaborative work among the actors in } \\
\text { the tourism industry }\end{array}$ & $\begin{array}{l}\text { Facilitates knowledge-flow } \\
\text { from centralized to distributed } \\
\text { for better capacity building }\end{array}$ \\
\hline $\begin{array}{c}\text { Srivastava } \\
\text { and } \\
\text { [67] }\end{array}$ & $\begin{array}{l}\text { Health access in } \\
\text { rural areas }\end{array}$ & $\begin{array}{l}\text { Service } \\
\text { Dominant Logic } \\
\text { (SDL) }\end{array}$ & $\begin{array}{l}\text { Simplify the complexity of resources } \\
\text { required to provide health service }\end{array}$ & $\begin{array}{l}\text { Improves accessibility and } \\
\text { affordability of service }\end{array}$ \\
\hline $\begin{array}{c}\text { (Andrade } \\
\text { and } \\
\text { Doolin } \\
\text { [68] }\end{array}$ & $\begin{array}{l}\text { Refugees' } \\
\text { adaptation in the } \\
\text { new society }\end{array}$ & $\begin{array}{l}\text { Sen's } \\
\text { Capability } \\
\text { Approach }\end{array}$ & $\begin{array}{l}\text { Leverage capability on understanding } \\
\text { (e.g. custom, history), communicating } \\
\text { (e.g. language barrier), participating } \\
\text { (event, promo), and connecting (e.g. } \\
\text { social media) }\end{array}$ & $\begin{array}{l}\text { Provide resources and } \\
\text { channels to build such } \\
\text { capabilities }\end{array}$ \\
\hline $\begin{array}{c}\text { Venkatesh } \\
\text { et al. [69] }\end{array}$ & $\begin{array}{l}\text { Infant mortality } \\
\text { rates in rural areas }\end{array}$ & $\begin{array}{l}\text { Social } \\
\text { epidemiology } \\
\text { and social } \\
\text { network }\end{array}$ & $\begin{array}{l}\text { Challenge and transform the social } \\
\text { pressure and orthodox custom or myth } \\
\text { on healthcare behaviors }\end{array}$ & $\begin{array}{l}\text { Information dissemination and } \\
\text { knowledge access }\end{array}$ \\
\hline
\end{tabular}

\section{Discussion}

\subsection{Characterizing ICT4D Research Streams}

The analyses of literature provide evidence of characteristics of each stream. Technology-transfer stream is characterized by technology diffusion and acceptance as its central discourse and quantitative approach as its primary methodology. The strength of studies in this stream lies in their ability to present a conclusive report to non-IS entities such as policy makers, funding bodies, and technology vendors. However, this stream is also somewhat limited because it fails to reveal any possible conflicting situation emanated from the complexity of the context that potentially hinders successful adoption $[19,70,71]$. This is prevalent since most studies in this stream limit their unit of analysis to a singlelevel. Further, the analytical lenses frequently used in these studies are not designed to engage with deep socio-technical explorations [72, 73].

The merit of social-embedded studies is in exploring the complexity of the context of ICT4D. Unlike technology-transfer studies, social-embedded research engages with a deeper investigation of the social system and interplay between actors and technology. However, conducting social-embedded research might be challenging for the researchers. It requires a thoughtful selection and interpretation of the contextual data collected during field study that might be abundant [8, p. 26]. It might become a major issue since gaining trust and collecting unbiased information from participants is challenging [22].

Transformative ICT4D studies inherit the strengths of social embedded stream. However, unlike the social-embedded stream that views the socio-technical interplay mechanism as a 'status quo', this stream proposes the transformative and revolutionary role of ICT in resolving the development struggle faced by developing countries. Thus, the researchers are usually required to take a "painstaking study" [72, p. ix] in the context which might become an issue since finding and establishing access and resources for this type of research in the developing countries is also challenging.

\subsection{Towards Holistic ICT4D Research}

Understanding the characteristics of each stream is a fundamental step toward broader and holistic 
ICT4D, either by combining each research characteristics or by extending each particular stream. They can be accomplished in several ways. As argued in $[16,19,72]$, the avenue for a broader and holistic ICT4D, is based on twofold: 1) to span the time of examination, or 2) to extend the scope of analysis. The first premise lies on the argument that studies on ICT and development should be in conjunction with adequate knowledge of the extant progression of the context in sufficient time period. Thus, there is no instant way to generate understanding of the phenomena related to ICT and development due the complexity involved within the social context and the interaction with technologies. As such, we acknowledge the importance of the timespan factor in ICT4D research to ensure researchers have sufficient time to obtain a conclusive finding (as in technology-transfer stream) and at the same time investigate the underlying mechanisms of how ICT contributes to development (as in transformative stream). The work by Venkatesh et al. [69] is an example of that illustrates the benefits of considering the timespan factor.

Second, that the investigation on the local context of ICT implementation should be linked with the macro-level socio-political situation where supporting systems, interrelated actors and resources, and social structure take place [19]. In this matter, we acknowledge the importance of the broader scope of analysis of the context in ICT4D studies. As such, a multilevel analysis with appropriate bridging between macro and micro-level shown in social-embedded stream (Table 4) can be considered as a solution for holistic and broader ICT4D. Indeed, choosing the theoretical lens for conducting socio-technical phenomena is not an easy job. While social theories, such as institutional theory or ANT, provide useful terms to explicate the technology and social actors, the researchers need to be cautious on the extent to which the theories inform their research. For example, the institutional theory would be more useful if it is combined with other perspectives in IS study [74], rather than be constrained by the terminologies from the theory.

Another important insight emerged from our analyses is related to the potential of critical realist research in building a holistic understanding of ICT4D [21, 22]. The significance of this study is to uncover any discrepancy occurred between monitoring and support in macro-level and ICT implementation in micro-level. For example, study by Lin et al [22] found a conflicting story in an ICT project that introduced computer, wireless, and internet in Taiwan's aboriginal village. While the government, private business, and related council were told that the project was tremendously successful, the study suggests a contradictory story at the bottom where the people "... could not see any benefit" and further "... became apathetic toward the end of the project" [22, p. 709]. To summarize, Table 6 presents the compilation of each stream and a brief proposition toward a broader and holistic ICT4D based on the findings emerged from our literature analysis.

Table 6. Comparison and Premise for a Consolidation of ICT4D Streams

\begin{tabular}{|l|l|l|l|}
\hline \multicolumn{1}{|c|}{ Properties } & \multicolumn{1}{|c|}{ Technology-transfer } & \multicolumn{1}{c|}{ Social-embedded } & \multicolumn{1}{c|}{ Transformative } \\
\hline Research methods & Mainly quantitative & Qualitative & Qualitative \\
\hline Theoretical lens & $\begin{array}{l}\text { Mostly IT Acceptance and } \\
\text { Adoption theories (e.g. TAM, } \\
\text { UTAUT), and Econometric } \\
\text { measurement of IT Impact }\end{array}$ & $\begin{array}{l}\text { Mostly social science } \\
\text { perspective (Actor-Network } \\
\text { Theory, institutional theory), } \\
\text { and a critical realist } \\
\text { (postcolonial, morphogenetic) }\end{array}$ & $\begin{array}{l}\text { Mostly social capital and } \\
\text { capability approach }\end{array}$ \\
\hline Level of analysis & $\begin{array}{l}\text { Single level: user (individual), } \\
\text { organization, or country }\end{array}$ & Multilevel analysis & Country-level, Community-level \\
\hline $\begin{array}{l}\text { Means of } \\
\text { development }\end{array}$ & $\begin{array}{l}\text { Diffusion and acceptance } \\
\text { through ICT use and impact }\end{array}$ & $\begin{array}{l}\text { Creation of new social practices } \\
\text { based on complex social system } \\
\text { that constrain the new ICT }\end{array}$ & $\begin{array}{l}\text { Resolving vulnerabilities and } \\
\text { leveraging capabilities }\end{array}$ \\
\hline $\begin{array}{l}\text { Approach for a } \\
\text { broader and } \\
\text { holistic ICT4D }\end{array}$ & $\begin{array}{l}\text { To span the time of examination, } \\
\text { either by longitudinal study or } \\
\text { by direct involvement of the } \\
\text { researchers to deeply understand } \\
\text { the context (e.g. ethnography or } \\
\text { action research) }\end{array}$ & $\begin{array}{l}\text { Appropriately uses, adjusts or } \\
\text { extends the theoretical lens to fit } \\
\text { with the complexity of the } \\
\text { context. The studies should be } \\
\text { carried out beyond one level of } \\
\text { analysis to link them to generate } \\
\text { holistic understanding of the } \\
\text { context }\end{array}$ & $\begin{array}{l}\text { A longitudinal investigation, or } \\
\text { a critical realist research }\end{array}$ \\
\hline
\end{tabular}




\section{Conclusions and Limitations}

We reviewed extant ICT4D research published in leading IS journals between 2007-2016, identified the characteristics of ICT4D streams published and discusses how each stream can be consolidated for a broader and holistic ICT4D. The findings suggest a few approaches for such a consolidation drawn upon the literature. Nevertheless, a broader and holistic perspective might be not a panacea that works in every case of ICT4D. The availability of resources might be the main obstacle for the researchers who seek a holistic understanding of the context. However, as prior scholars suggested, any significant effort not to isolate between technology and the society in the context of developing countries is desperately required

This study has several limitations. First, it only selected publication from general IS outlets. As an interdisciplinary field, ICT4D has invited scholars from various fields. Thus, including studies from respective outlets may represent a more comprehensive trend of each stream and enable a cross-disciplinary analysis. Especially, we invite further studies focusing on specialized ICT4D journals that recently have been significantly improved and indexed by Scopus or Web of Science citation database Second, it relied on the Scopus citation database system as search engine, where some articles might be missed because of incomplete abstract or keyword stored in this system.

\section{Acknowledgement}

This paper derives from the first author's doctoral study sponsored by Lembaga Pengelola Dana Pendidikan (LPDP) Kementerian Keuangan Republik Indonesia.

\section{References}

[1] A. Ayanso, D. I. Cho, and K. Lertwachara, "Information and communications technology development and the digital divide: A global and regional assessment," Information Technology for Development, vol. 20, no. 1, pp. 60-77, 2014.

[2] T. Unwin, ICT4D: Information and Communication Technology for Development. Cambridge: Cambridge University Press, 2009.

[3] R. Montealegre, "Waves of change in adopting the Internet: Lessons from four Latin American Countries," Information Technology \& People, vol. 11, no. 3, pp. 235-260, 1998.

[4] D. A. Mirchandani, J. H. Johnson, and K. Joshi, "Perspectives of citizens towards e-government in Thailand and Indonesia: A multigroup analysis," Information Systems Frontiers, vol. 10, no. 4, pp. 483497, 2008 .
[5] R. Heeks, "Information systems and developing countries: failure, success, and local improvisations," The Information Society, vol. 18, no. 2, pp. 101-112, 2002.

[6] D. H. Brown and S. Thompson, "Priorities, policies and practice of e-government in a developing country context: ICT infrastructure and diffusion in Jamaica," European Journal of Information Systems, vol. 20, no. June 2009, pp. 329-342, 2011.

[7] E. H. Diniz, D. E. Bailey, and D. Sholler, "Achieving ICT4D Project Success by Altering Context, Not Technology," Information Technologies \& International Development, vol. 10, no. 4, pp. 15-29, 2014.

[8] N. Hayes and C. Westrup, "Context and the processes of ICT for development," Information and Organization, vol. 22, no. 1, pp. 23-36, 2012.

[9] J. Braa, E. Monteiro, and E. S. Reinert, "Technology Transfer vs. Technological Learning: IT infrastructure and health care in developing countries," Information Technology for Development, vol. 6, no. 1, pp. 15-23, 1995.

[10] G. Walsham and S. Sahay, "GIS for District-Level Administration in India: Problems and Opportunities," MIS Quarterly, vol. 23, no. 1, pp. 39-66, 1999.

[11] J. Barjis, G. Kolfschoten, and J. Maritz, "A sustainable and affordable support system for rural healthcare delivery," Decision Support Systems, vol. 56, no. 1, pp. 223-233, 2013.

[12] B. Dey, D. Newman, and R. Prendergast, "Analysing appropriation and usability in social and occupational lives," Information Technology \& People, vol. 24, no. 1, pp. 46-63, 2011.

[13] F. D. Davis, "Perceived Usefulness, Perceived Ease of Use, and User Acceptance of Information Technology," MIS Quarterly, vol. 13, no. 3, pp. 319340, 1989.

[14] V. Venkatesh, M. G. Morris, G. B. Davis, and F. D. Davis, "User Acceptance of Information Technology: Toward a Unified View," MIS Quarterly, vol. 27, no. 3, pp. 425-478, 2003.

[15] C. Avgerou, "Information systems in developing countries: A critical research review," Journal of Information Technology, vol. 23, no. 3, pp. 133-146, 2008.

[16] C. Avgerou, "Discourses on ICT and Development," Information Technologies \& International Development, vol. 6, no. 3, pp. 1-18, 2010.

[17] R. Gera, N. Muthusamy, A. Bahulekar, A. Sharma, P. Singh, A. Sekhar, and V. Singh, "An in-depth assessment of India's Mother and Child Tracking System (MCTS) in Rajasthan and Uttar Pradesh.," BMC health services research, vol. 15 , no. 315 , pp. 114, 2015.

[18] S. Sahay, "Are We Building a Better World with ICTs? Empirically Examining This Question in The Domain of Public Health in India," Information Technology for Development, vol. 22, no. 1, pp. 168-176, 2016.

[19] S. Madon, S. Sahay, and R. Sudan, "E-Government Policy and Health Information Systems Implementation in Andhra Pradesh, India: Need for Articulation of 
Linkages Between the Macro and the Micro," The Information Society, vol. 23, no. 5, pp. 327-344, 2007.

[20] M. Thompson and G. Walsham, "ICT Research in Africa: Need for a Strategic Developmental Focus," Information Technology for Development, vol. 16, no. 2, pp. 112-127, 2010.

[21] J. M. Njihia and Y. Merali, "The Broader Context for ICT4D Projects: A Morphogenetic Analysis," MIS Quarterly, vol. 37, no. 3, pp. 881-905, 2013.

[22] C. I. C. Lin, F.-Y. Kuo, and M. D. Myers, "Extending ICT4D Studies: The Value of Critical Research," MIS Quarterly, vol. 39, no. 3, pp. 697-712, 2015.

[23] G. Walsham, "ICTS for The Broader Development of India: An Analysis of the Literature," Electronic Journal of Information Systems in Developing Countries, vol. 41, no. 4, pp. 1-20, 2010.

[24] E. M. Rogers, Diffusion of innovations. Free Press of Glencoe, 1962.

[25] S. Sahay, J. Sæbø, and J. Braa, "Scaling of HIS in a global context: Same, same, but different," Information and Organization, vol. 23, no. 4, pp. 294-323, 2013.

[26] S. A. Mengiste and M. Aanestad, "Understanding the dynamics of learning across social worlds: A case study from implementing IS in the Ethiopian public health care system," Information and Organization, vol. 23, no. 4, pp. 233-257, 2013.

[27] R. Gomez, "The changing field of ICTD: Growth and maturation of the field, 2000-2010," Electronic Journal of Information Systems in Developing Countries, vol. 58, no. 1, pp. 1-21, 2013.

[28] S. Sahay and G. Walsham, "Information technology in developing countries: A need for theory building," Information Technology for Development, vol. 6, no. 3-4, pp. 111-124, 1995.

[29] L. Dodson, S. R. Sterling, and J. K. Bennett, "Considering Failure: Eight Years of ITID Research," International Journal for Service Learning in Engineering, vol. 9, no. 2, pp. 19-34, 2013.

[30] A. Imran and S. Gregor, "Uncovering the Hidden Issues in E-Government Adoption in a Least Developed Country: The Case of Bangladesh," Journal of Global Information Management, vol. 18, no. 2, pp. 30-56, 2010.

[31] A. Brown and G. Grant, "Highlighting the Duality of the ICT and Development Research Agenda," Information Technology for Development, vol. 16, no. 2, pp. 96-111, 2010.

[32] Z. Meng and S. Y. T. Lee, "The value of IT to firms in a developing country in the catch-up process: An empirical comparison of China and the United States," Decision Support Systems, vol. 43, no. 3, pp. 737-745, 2007.

[33] D. Arnott, W. Jirachiefpattana, and P. O'Donnell, "Executive information systems development in an emerging economy," Decision Support Systems, vol. 42, no. 4, pp. 2078-2084, 2007.

[34] J. Tan, K. Tyler, and A. Manica, "Business-to-business adoption of eCommerce in China," Information and Management, vol. 44, no. 3, pp. 332-351, 2007.

[35] M. O. S. Mahdi and P. Dawson, "The introduction of information technology in the commercial banking sector of developing countries: voices from Sudan," Information Technology \& People, vol. 20, no. 2, pp. 184-204, 2007.

[36] B. Zarei and A. Ghapanchi, "Guidelines for government-to-government initiative architecture in developing countries," International Journal of Information Management, vol. 28, no. 4, pp. 277-284, 2008.

[37] B. Gupta, S. Dasgupta, and A. Gupta, "Adoption of ICT in a government organization in a developing country: An empirical study," Journal of Strategic Information Systems, vol. 17, no. 2, pp. 140-154, 2008.

[38] K. Masters, "Access to and use of the Internet by South African general practitioners," International Journal of Medical Informatics, vol. 77, no. 11, pp. 778-786, 2008.

[39] R. Kuriyan, I. Ray, and K. Toyama, "Information and Communication Technologies for Development: The Bottom of the Pyramid Model in Practice," The Information Society, vol. 24, no. 2, pp. 93-104, 2008.

[40] N. Park, R. Roman, S. Lee, and J. E. Chung, "User acceptance of a digital library system in developing countries: An application of the Technology Acceptance Model," International Journal of Information Management, vol. 29, no. 3, pp. 196-209, 2009.

[41] W. T. Lin, "The business value of information technology as measured by technical efficiency: Evidence from country-level data," Decision Support Systems, vol. 46, no. 4, pp. 865-874, 2009.

[42] P. Meso, P. Musa, D. Straub, and V. Mbarika, "Information infrastructure, governance, and socioeconomic development in developing countries," European Journal of Information Systems, vol. 18, pp. 52-65, 2009.

[43] B. Kijsanayotin, S. Pannarunothai, and S. M. Speedie, "Factors influencing health information technology adoption in Thailand's community health centers: Applying the UTAUT model," International Journal of Medical Informatics, vol. 78, no. 6, pp. 404-416, 2009.

[44] S. Dewan, D. Ganley, and K. L. Kraemer, "Complementarities in the diffusion of personal computers and the internet: Implications for the global digital divide," Information Systems Research, vol. 21, no. 4, pp. 925-940, 2010.

[45] C. Okoli, V. W. a Mbarika, and S. McCoy, "The effects of infrastructure and policy on e-business in Latin America and Sub-Saharan Africa," European Journal of Information Systems, vol. 19, no. 1, pp. 5-20, 2010.

[46] R. Gomez and E. Gould, "The 'cool factor' of public access to ICT," Information Technology \& People, vol. 23, no. 3, pp. 247-264, 2010.

[47] P. Datta, "A preliminary study of ecommerce adoption in developing countries," Information Systems Journal, vol. 21, no. 1, pp. 3-32, 2011.

[48] S. Lee, J. Y. Xiang, and J. K. Kim, "Information technology and productivity: Empirical evidence from the Chinese electronics industry," Information \& Management, vol. 48, no. 2-3, pp. 79-87, 2011.

[49] J. B. Pick and R. Azari, "A Global Model of Technological Utilization Based on Governmental, 
Business-Investment, Social, and Economic Factors," Journal of Management Information Systems, vol. 28, no. 1, pp. 49-84, 2011.

[50] M. M. M. A. Riffai, K. Grant, and D. Edgar, "Big TAM in Oman: Exploring the promise of on-line banking, its adoption by customers and the challenges of banking in Oman," International Journal of Information Management, vol. 32, no. 3, pp. 239-250, 2012.

[51] M. Alomari, P. Woods, and K. Sandhu, "Predictors for e-government adoption in Jordan," Information Technology \& People, vol. 25, no. 2, pp. 207-234, 2012.

[52] J. Dedrick, K. L. Kraemer, and E. Shih, "Information Technology and Productivity in Developed and Developing Countries," Journal of Management Information Systems, vol. 30, no. 1, pp. 97-122, 2013.

[53] J. W. Lian, D. C. Yen, and Y. T. Wang, "An exploratory study to understand the critical factors affecting the decision to adopt cloud computing in Taiwan hospital," International Journal of Information Management, vol. 34, no. 1, pp. 28-36, 2014.

[54] V. Venkatesh, T. A. Sykes, and S. Venkatraman, "Understanding e-Government portal use in rural India: Role of demographic and personality characteristics," Information Systems Journal, vol. 24, no. 3, pp. 249269, 2014.

[55] N. P. Rana, Y. K. Dwivedi, B. Lal, M. D. Williams, and M. Clement, "Citizens' adoption of an electronic government system: towards a unified view," Information Systems Frontiers, pp. 1-20, 2015.

[56] S. Kurnia, R. J. Karnali, and M. M. Rahim, "A qualitative study of business-to-business electronic commerce adoption within the Indonesian grocery industry: A multi-theory perspective," Information and Management, vol. 52, no. 4, pp. 518-536, 2015.

[57] H. M. Sabi, F. E. Uzoka, K. Langmia, and F. N. Njeh, "Conceptualizing a model for adoption of cloud computing in education," International Journal of Information Management, vol. 36, no. 2, pp. 183-191, 2016.

[58] V. Venkatesh and T. A. Sykes, "Digital Divide Initiative Success in Developing Countries: A Longitudinal Field Study in a Village in India," Information Systems Research, vol. 24, no. 2, pp. 239260, 2013.

[59] J. Braa, O. Hanseth, A. Heywood, W. Mohammed, and V. Shaw, "Developing health information systems in developing countries: The flexible standards strategy," MIS Quarterly, vol. 31, no. 2, pp. 381-402, 2007.

[60] P. Gao, "Counter networks in standardization: a perspective of developing countries," Information Systems Journal, vol. 17, no. 4, pp. 391-420, 2007.

[61] A. Prakash and R. De', "Importance of development context in ICT4D projects," Information Technology \& People, vol. 20, no. 3, pp. 262-281, 2007.
[62] S. K. Puri, S. Sahay, and J. Lewis, "Building participatory HIS networks: A case study from Kerala, India," Information and Organization, vol. 19, no. 2, pp. 63-83, 2009.

[63] S. R. de Brito, A. do Socorro da Silva, E. C. da Mata, N. L. Vijaykumar, C. A. J. da Rocha, M. de Abreu Monteiro, J. C. W. A. Costa, and C. R. L. Francês, "An approach to evaluate large-scale ICT training interventions," Information Systems Frontiers, 2016.

[64] G. Miscione, "Telemedicine in the Upper Amazon: Interplay with Local Health Care Practices," MIS Quarterly, vol. 31, no. 2, pp. 403-425, 2007.

[65] C. Urquhart, S. Liyanage, and M. M. O. Kah, "ICTs and poverty reduction: A social capital and knowledge perspective," Journal of Information Technology, vol. 23 , no. 3, pp. 203-213, 2008.

[66] M. S. Adam and C. Urquhart, "No man is an island: Social and human capital in IT capacity building in the Maldives," Information and Organization, vol. 19, no. 1, pp. 1-21, 2009.

[67] S. C. Srivastava and G. Shainesh, "Bridging the Service Divide Through Digitally Enabled Service Innovations: Evidence from Indian Healthcare Service Providers.," MIS Quarterly, vol. 39, no. 1, pp. 245268, 2015.

[68] A. D. Andrade and B. Doolin, "Information and Communication Technology and the Social Inclusion of Refugees," MIS Quarterly, vol. 40, no. 2, pp. 405416, 2016.

[69] V. Venkatesh, A. Rai, T. A. Sykes, and R. Aljafari, "Combating Infant Mortality in Rural India: Evidence from a field study of eHealth Kiosk Implementations," MIS Quarterly, vol. 40, no. 2, pp. 353-380, 2016.

[70] W. L. Currie and M. W. Guah, "Conflicting institutional logics: A national programme for IT in the organisational field of healthcare," Journal of Information Technology, vol. 22, no. 3, pp. 235-247, 2007.

[71] M. Findikoglu and M. B. Watson-Manheim, "Linking macro-level goals to micro-level routines: EHRenabled transformation of primary care services," Journal of Information Technology, vol. 31, no. October, pp. 382-400, 2016.

[72] S. Madon, E-governance for Development: A Focus on Rural India. London: Palgrave Macmillan, 2009.

[73] G. Walsham, "ICT4D research: reflections on history and future agenda," Information Technology for Development, vol. 1102, no. April, pp. 1-24, 2017.

[74] V. Weerakkody, Y. K. Dwivedi, and Z. Irani, "The diffusion and use of institutional theory: A crossdisciplinary longitudinal literature survey," Journal of Information Technology, vol. 24, no. 4, pp. 354-368, 2009. 